\title{
David Oliver: Leaving medicine-is the grass always greener?
}

\section{David Oliver consultant in geriatrics and acute general medicine}

Berkshire

Across training grades in hospital specialties we have fewer doctors entering core training after foundation years, ${ }^{1}$ and fewer progress from core training to higher specialty training. ${ }^{2}$

It's too early to say how many doctors who have stepped out of a training programme will give up their medical registration for good, re-enter training grades, or return from working overseas. It's each doctor's prerogative to decide when to have a break, a clean break, a change of pace, or a change of career. And we should offer adequate mentorship and support to those who are struggling, uncertain, or contemplating a life changing decision after years of personal investment in training. It's surely crucial to ask, "What would you do instead, and would it be any easier or more fulfilling?"

Those who move to other health systems sometimes report better terms and conditions and work-life balance. But these systems can't keep absorbing UK medical graduates, especially in popular urban centres.

Without the NHS's salary structure we find huge pay differentials between specialties and nothing like the security or value of the NHS pension. Indemnity costs and the bureaucracy of billing for activity can be burdensome, and other health systems have their own problems and disgruntled doctors.

Other key public sector roles in, say, teaching, policing, social care, local government, NHS management, and the civil service have all faced worse austerity and cutbacks than medicine. University academia is fiercely competitive and insecure, and the pay is far lower than in medicine. Lawyers and barristers doing public legal aid work have the insecurity of self employed freelancers, compounded by reduced rates.

Teaching, policing, social care, NHS management, and the civil service have all faced worse austerity and cutbacks than medicine

What about the private sector? Well, news media are highly competitive, and print journalism is dying slowly. Doctors have the academic ability to retrain in other learned professions such as accountancy. A proportion could find lucrative niche work applying their medical backgrounds to technology, management consultancy, finance, or the drug industry. But they'd be playing catch-up with people who started those careers much younger. Self employment and start-up businesses bring a different set of stresses alongside the promise of freedom and flexibility.

Some corporate employers may pay better than the NHS, albeit without its job security and pension entitlement. Some may make staff feel better valued and supported. But they won't consistently top the poll of public respect, as healthcare professionals do. Nor will they necessarily offer the professional satisfaction, fulfilment, and human contact that medicine can. And the personal values that drew many into careers as NHS doctors could seriously jar with industries whose key drivers are profit and competition.

I'd never judge any doctor for leaving. I'd only urge those eyeing the exit door, from what has come to feel like a bleak house, to consider whether the grass really is greener outside.

Competing interests: See www.bmj.com/about-bmj/freelancecontributors/david-oliver.

Provenance and peer review: Commissioned; not externally peer reviewed.

Follow David on Twitter: @mancunianmedic

1 Rimmer A. Half of foundation trainees now choose not to progress straight to specialty training. BMJ Careers 2 Feb 2017. http://careers.bmj.com/careers/advice/Half_of foundation trainees now choose not to progress straight to specialty training.

2 Kennedy C. Specialty training applications for entry in 2016: competition ratios and the application process. BMJ Careers 9 Nov 2015. http://careers.bmj.com/careers/advice/ Specialty_training_applications_for_entry_in_2016\%3A_competition_ratios_and_the_ application process.

Published by the BMJ Publishing Group Limited. For permission to use (where not already granted under a licence) please go to http://group.bmj.com/group/rights-licensing/ permissions 